\section{Insulin receptor antibodies causing steroid responsive diabetes mellitus in a patient with myositis}

Insulin receptor antibodies may form in patients with acanthosis nigricans ${ }^{1}$ and systemic lupus erythematosus. ${ }^{2}$ They cause severe insulin resistance and may lead to diabetes mellitus. We describe a patient with eosinophilic polymyositis and diabetes who had insulin receptor antibodies and raised serum immunoreactive insulin concentrations.

\section{Case history}

A 21 year old Saudi woman presented with myalgia, weakness, and polyarthralgia for $\mathbf{1 5}$ days which had developed after fever, malaise, and a sore throat. She was not obese, had gross proximal myopathy, muscle greatly improved her glucose tolerance and myopathy. Steroids cause similar improvement in patients with insulin receptor antibodies, insulin resistance, and acanthosis nigricans. ${ }^{4}$ The impairment in glucose tolerance was mild despite a $49 \%$ inhibition of maximum binding at a one in 10 dilution of the patient's serum. Interestingly, a similar degree of inhibition of insulin binding by sera of patients with acanthosis nigricans is associated with massive insulin resistance. ${ }^{14}$ This discrepancy suggests that factors other than inhibitors of binding may be important in the pathogenesis of diabetes mellitus in patients with acanthosis nigricans who have insulin receptor antibodies.

Reportedly, IgG's from sera containing insulin receptor antibodies are highly stimulatory to adipocyte metabolism in vitro, and this paradoxical stimulatory activity in vitro accounts for the intractable hypoglycaemia which occurs in some patients with acanthosis nigricans and insulin receptor antibodies." The inability of our patient's IgG to produce any greater stimulation of adipocytes than control IgG suggests that not all insulin receptor antibodies have a specific insulinomimetic effect distinct from that exerted by normal

Blood glucose and serum immunoreactive insulin concentrations measured during glucose tolerance tests (50 $\mathrm{g})$ before and after treatment with steroids and on relapse, and $\mathrm{Hb} \mathrm{A}_{1}$ values before treatment and on relapse. (Only fasting insulin concentration measured during steroid induced remission)

\begin{tabular}{|c|c|c|c|c|c|c|c|c|}
\hline & & \multicolumn{3}{|c|}{ Before steroids } & \multicolumn{2}{|c|}{ After steroids } & \multicolumn{2}{|c|}{ Relapse } \\
\hline & & $\begin{array}{r}\text { Glucose } \\
(\mathrm{mmol} / \mathrm{l})\end{array}$ & $\underset{(\mathrm{mU} / \mathrm{I})}{\text { Insulin }}$ & $\underset{(\%)}{\mathbf{H b A}_{\mathbf{1}}}$ & $\begin{array}{c}\text { Glucose } \\
(\mathrm{mmol} / \mathrm{l})\end{array}$ & $\underset{(\mathrm{mU} / \mathbf{1})}{\text { Insulin* }}$ & $\begin{array}{c}\text { Glucose } \\
(\mathrm{mmol} / \mathrm{l})\end{array}$ & $\underset{(\%)}{\mathbf{H b A}_{1}}$ \\
\hline $\begin{array}{l}\text { Time after glucose load (minutes) } \\
\mathrm{HbA}_{\mathbf{1}}\end{array}$ & $\begin{array}{r}0 \\
30 \\
60 \\
90 \\
120\end{array}$ & $\begin{array}{r}5 \cdot 2 \\
7 \cdot 8 \\
9 \cdot 6 \\
10 \cdot 1 \\
10 \cdot 9\end{array}$ & $\begin{array}{l}25 \\
44 \\
76 \\
83 \\
90\end{array}$ & 8 & $\begin{array}{l}4 \cdot 4 \\
5 \cdot 4 \\
7 \cdot 1 \\
6 \cdot 9 \\
6 \cdot 1\end{array}$ & 8 & $\begin{array}{r}5 \cdot 3 \\
7 \cdot 3 \\
10 \cdot 0 \\
10 \cdot 6 \\
10 \cdot 3\end{array}$ & $7 \cdot 5$ \\
\hline
\end{tabular}

* Normal fasting immunoreactive insulin concentration $<10 \mathrm{mU} / \mathrm{l}$.

Conversion: SI to traditionalunits-Glucose: $1.0 \mathrm{mmol} / 1 \approx 18.0 \mathrm{mg} / 100 \mathrm{ml}$

tenderness, and diffuse vitiligo. Haemoglobin concentration was $10 \mathrm{~g} / \mathrm{dl}$ and leucocyte count $17 \times 10^{\circ} / 1$ (39\% neutrophils, $16 \%$ lymphocytes, $3 \%$ monocytes, $42 \%$ eosinophils). Plasma urea, electrolyte, and creatinine concentrations were normal, as were the results of liver function tests. Creatine kinase activity was $1621 \mathrm{IU} / \mathrm{l}$. She had glycosuria, and a random blood glucose estir.1ation yielded $10 \mathrm{mmol} / 1(180 \mathrm{mg} / 100 \mathrm{ml})$. Rheumatoid factor and antinuclear and anti-DNA antibodies were absent. Electromyography and muscle biopsy confirmed polymyositis.

A glucose tolerance test showed mild diabetes mellitus with hyperinsulinaemia (table). The patient was treated with oral prednisolone $40 \mathrm{mg}$ daily, and within one week her muscle power had improved dramatically. Results of a repeat glucose tolerance test and a fasting immunoreactive insulin concentration were normal. The remission was maintained with $20 \mathrm{mg}$ prednisolone given on alternate days.

Six months later the patient stopped the prednisolone and a relapse of polymyositis and glucose intolerance ensued. Reintroduction of prednisolone again induced and maintained remission.

Serum taken during the active phase of the illness was tested for its ability to inhibit the binding of insulin to insulin receptors in human placenta membranes, as follows: $17,23,34,43$, and $49 \%$ inhibition was found at dilutions of one in $200,100,40,20$, and 10 respectively. IgG prepared from the patient's serum by protein A Sepharose chromatography was tested in the adipocyte lipogenesis system. ${ }^{3}$ The stimulatory effect of the patient's IgG was less than that of control IgG $(451 \% v 672 \%$ stimulation at $25 \mathrm{mg}$ $\operatorname{IgG} / 1)$.

\section{Comment}

The mild diabetes in this patient was probably of short duration (normal $\mathrm{HbA}_{1}$ value) and had probably developed at the same time as her polymyositis. The inhibition of insulin binding to human placental receptors by her serum in association with the raised fasting insulin concentrations and diabetic glucose tolerance test result suggested insulin resistance secondary to a circulating immunoglobulin. Treatment with steroids (often diabetogenic at high doses)
IgG. ${ }^{3}$ Hence the insulinomimetic, hypoglycaemic effect of insulin receptor antibodies ${ }^{5}$ must presumably be confined to a specific class of these autoantibodies.

We thank Dr J Olefsky, University of California, USA, for performing the insulin binding studies and Pamela Dale and Joan Singh for preparing the manuscript.

1 Kahn CR, Flier JS, Bar RS, et al. The syndromes of insulin resistance and acanthosis nigricans. N Engl f Med 1976;294:739-45.

2 Omori Y, Minei S, Saito M, Tsushima T, Hirata Y. Insulin-receptor auto-antibodies detected by the human placental membrane method: six patients with insulin receptor antibody detected in Japan. Tohokuf Exp Med 1982;138:319-28.

${ }^{3}$ Khokher MA, Janah S, Dandona P. Human immunoglobulin G stimulates human adipocyte lipogenesis. Diabetologia 1983;25:264-8.

${ }^{4}$ Flier JS, Bar RS, Muggeo M, Kahn CR, Roth J, Gorden P. The evolving clinical course of patients with insulin receptor autoantibodies: spontaneous remission or receptor proliferation with hypoglycemia. f Clin Endocrinol Metab 1978;47:985-95.

5 Dons RF, Havlik R, Taylor SI, Baird KL, Chernick SS, Gorden P. Clinical disorders associated with autoantibodies to insulin receptor. Simulation by passive transfer to rats. $\mathcal{F}$ Clin Invest $1983 ; 72: 1072-80$.

(Accepted 9 February 1984)

Department of Medicine, King Saud University, Riyadh, Saudi Arabia

V FONSECA, MD, MRCP, assistant professor

Metabolic Unit, Department of Chemical Pathology, Royal Free Hospital and School of Medicine, London NW3 2QG

M A KHOKHER, MSC, PHD, research fellow

P DANDONA, MRCP, DPHIL, director of metabolic unit and senior lecturer

Correspondence to: Dr P Dandona. 